\title{
HISTOLOGICAL AND IMMUNOHISTOCHEMICAL EVALUATIONS OF RAT SOFT TISSUE RESPONSE TO BIOCERAMICAL IMPLANTS
}

MARKOVIĆ DANICA*, KOJIĆ ZVEZDANA**, MARINKOVIĆ D***, DANILOVIĆ VESNA****, RADOVANOVIĆ ANITA* and JANAĆKOVIĆ $\Xi^{* * * * *}$

*Department of Histology and Embriology, Faculty of Veterinary Medicine, Belgrade; **Institute of Medical Physiology, School of Medicine; ${ }^{* \star \star}$ Department of Pathology, Faculty of Veterinary

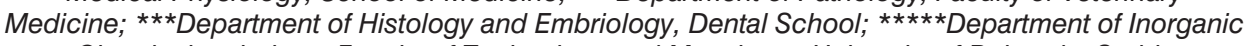
Chemical techology, Faculty of Technology and Mettalurgy, University of Belgrade, Serbia

(Received 9. January 2009)

The purpose of this study was to evaluate the tissue response induced by bioceramical materials (BCM) implanted in rat subcutaneous tissue. Thirty two rats were assigned to 6 groups, as following: control group i.e. not treated; dental ceramic (DC) implants; alfa tricalcium phosphate synthetised at $22 \mathrm{MPa}$ ( $\alpha$ TCP22) and at $45 \mathrm{MPa}(\alpha T C P 45) ;$ hydroxyapatite synthetised at $22 \mathrm{MPa}$ (HAP22) and at $45 \mathrm{MPa}$ (HAP45). Contra lateral sides of all test animals represented the blank control surgically incisied at the paravertebral sockets. The experimental groups received subcutaneous implants of the test BCM materials. Samples were collected after 14 days and processed histologically. Inflammatory reactions were noted microscopically. The inflammatory infiltrate consisted of lymphocytes, polimorphonuclears, macrophages and mastocytes. At same time there were signs of increased fibrosis around the graft places.

In conclusion, the implant sides compared with surgical incision wounds induced a foreign body-type granuloma with subsequent fibrosis around the grafts. The presence of a capsule at the interface with $B C M$ in rat subcutis did not elicit any remarkable immune responses, thus being considered biocompatible. By evaluating different responses according to $B C M$, the most intense tissue reaction was noticed at HAP45, graded as severe, and mild to moderate for DC, HAP22 and alfa tricaltium phosphate.

Key words: bioceramics, biocompatibility, histology, subcutaneous tissue

\section{INTRODUCTION}

Under physicochemical stimulations some signals will be generated at the cell level within the tissue and they regulate metabolic and biosynthetic activities. 
The extracellular matrix makes the cell-matrix interactions which affect cell signalling in the tissue and the generating processes (Butler et al., 2000).

Factors relating to the organization of the extracelular matrix macromolecules (e.g. various types of collagen and proteoglicans) (Hardingham and Fosang, 1992), and the heterogeneous cellular and compositional distributions within the tissue (Mow, 1998) play a significant role in defining the mechano-electrochemical environment around tissue cells. It is not known to which stimuli these cells are responding (e.g., fluid pressure or solid stress, viscous shear stress, osmotic pressure or hydrodynamic pressure).

From the bioengineering viewpoint, the lack of knowledge of cell-regulating signals is due, in part, to the difficulty of developing detailed and accurate constitutive laws for soft tissue and tissue cells (Tamai et al., 2007).

Biomaterials used in all medical devices and implants can be classified under two categories, namely: 1 . biological substitutes; 2 . synthetic materials which include: a) metallic, b) polymeric, c) ceramic, d) composite materials). Each of these materials has it own characteristics (Janackovic et al., 2003).

Ceramic materials, while very stabile and hard, suffer brittle fractures and cannot take on tensile forces (Sun and Leong, 2003). The tissue response to graft material is among other parameters, related to the characteristics of the material (Krsljak et al., 2005).

This investigation brings an integrated approach to the host tissue response after a 2 week implantation period with the aim to evaluate specificities of soft tissue reactions on different types of bioceramic materials, and comparing them with subcutaneous responses following surgical incision.

\section{MATERIAL AND METHODS}

\section{Materials}

The tested BCM were obtained at the Faculty of Technology and Metallurgy, Belgrade University: dental ceramic (DC); alfa tricalcium phosphate synthesised at $22 \mathrm{MPa}(\alpha \mathrm{TCP} 22)$; alfa tricalcium phosphate synthesised at $45 \mathrm{MPa}(\alpha \mathrm{TCP} 45)$; hidroxyapatite synthesised at $22 \mathrm{MPa}$ (HAP22); hidroxyapatite synthesised at 45 MPa (HAP45) (Figure 1).

Dental ceramic (DC) was obtained by the commercially made bioinert dental ceramics VITAVMK 95. The samples were prepared by mixing the ceramic powder with VITA modelling Fluid and shaped at $5 \times 2 \mathrm{~mm}$ diameter. The samples were air heated at $600^{\circ} \mathrm{C}$ for 6 minutes, and after that heated up to $930^{\circ} \mathrm{C}$ with the heating rate of $55^{\circ} \mathrm{C} / \mathrm{min}$ in vacuum. The cooled samples were after that glazed with Vita Akzent Powder mixed with Vita akzent Fluid, and heated at $600^{\circ} \mathrm{C}$ for 4 min.

The calcium phosphate materials were prepared chemically by synthesizing calcium-hydroxyapatite by the method of modified hydrothermal reaction of $\mathrm{Ca}(\mathrm{EDTA})^{2-}$ in phosphate solutions. The impact of concentrations of $\mathrm{Ca}^{2+}$ and $\mathrm{PO}_{4}{ }^{3-}-$ ions in the initial solution upon the morphology of synthesized HAP particles and attaining the $\alpha$-TCP phase after frying of obtained HAP powders was 
investigated. These materials were obtained at pressures of 22 and $45 \mathrm{Mpa}$ (Figure 1).

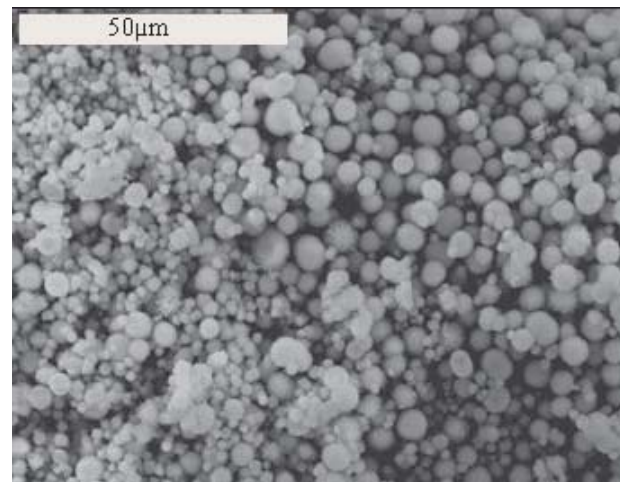

a) HAP1

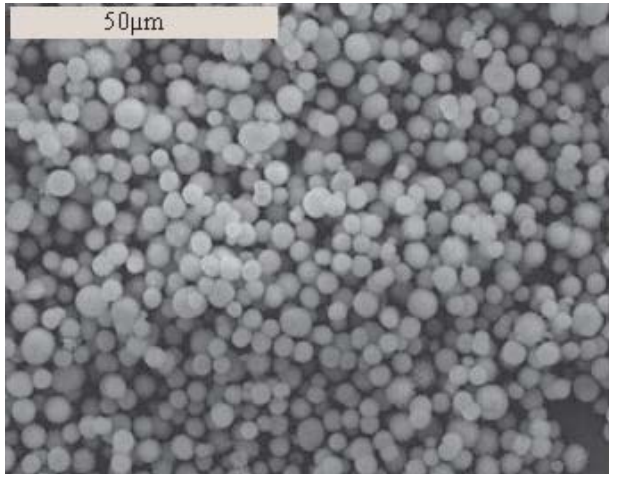

a) HAP2

Figure 1. SEM particules of HAP powder obtained by hydrothermal method and dried at 105ㅇ: a) HAP1, b) HAP2 were:

As the starting supstrates for the synthesis of calcium-hydroxyapatite used

- calcium-nitrate tetrahydrate, $\mathrm{Ca}\left(\mathrm{NO}_{3}\right)_{2} \cdot 4 \mathrm{H}_{2} \mathrm{O}$

- sodium salt of ethylenediamineted acetic acid (EDTA)

- sodium-phosphate dihydrate, $\mathrm{NaH}_{2} \mathrm{PO}_{4} \cdot 2 \mathrm{H}_{2} \mathrm{O}$

- urea, p.a. purity.

\section{Animals and husbandry}

Wistar-Albino rats $(n=32)$ of both sex (average weights $250 \mathrm{gr}$ ) obtained from the Vivarium of the Institute of Physiology, School of Medicine Belgrade University, were randomly assigned to 2 groups, as follows: control, treated and 5 groups with subcutaneous implants.

The animals were anesthetized with aether. The surgical field was shaved and disinfected and two parallel paravertebral skin incisions were made. The subcutaneous tissue on the place of the right incision was prepared in the form of a pocket which was used for implantation of BCM. Both incisions were sutured and an antiseptic stick was applied.

\section{Histological studies and immunostaining}

Two weeks after implantation the animals were measured and sacrificed by an overdose of aether. Tissue samples with implanted BCM, were fixed in 10\% buffered formalin for 24 - 48 hours. After standard processing in an automated tissue processor, tissue samples were embedded in paraffin blocks. The $5 \mu \mathrm{m}$ thick paraffin sections were stained with haematoxylin and eosin (H\&E) and toluidine blue (TB).

Immunohistologic investigation was performed with CD3 antibodies. After incubation primary antibodies (Polyclonal rabbit Antihuman CD3, DAKO, A0452, 
and secondary biotinized antibodies (antimouse / antirabbit from comercial kit for IHC - ChemMate DAKO Citomation, Danmark, catalogue number K5003, bottle A) were used. For visualisation chromogen-DAB (3,3' diaminobenzidin) has been used which coloured brown the positive reaction site.

\section{Biocompatibility of medical devices}

In this investigation ISO 10993 standards were used, specific to the testing and evaluation of local reactions to implanted materials. (Upman et al.,2004). The modification of ISO 10993-10:2002/ Amd 1: 2006 Biological evaluation of medical devices, Part 10: The test for irritation and delayed-type of hypersensitivity was also applied.

The grades for microscopical evaluations for all the animals in the test groups were calculated and the obtained sum divided by the number of observations to obtain a test group average for the irritant effects on soft tissues (Table 1).

Table 1. Irritation index of soft tissue reaction to BCM (Irl)

\begin{tabular}{|c|c|}
\hline $\begin{array}{c}\text { Irritation index of } \\
\text { soft tissue reaction to BCM }\end{array}$ & (Irl) \\
\hline Average grade & Description of response \\
\hline \hline 0 & None \\
\hline $1-5$ & Minimal \\
\hline $6-10$ & Mild \\
\hline $11-15$ & Moderate \\
\hline $16-20$ & Marked \\
\hline
\end{tabular}
of Medicine.

The study was conducted following the guidelines of the Belgrade School

\section{RESULTS}

Scores of the evaluation of soft tissue response for Irritation index (Iri) were given as follows: absent (0), minimal (1), mild (2), moderate (3), and marked (4). (Table 2).

Inflammatory infiltrate and fibrosis intensity around the graft particles were analysed semi-quantitatively, under light microscopy attributing scores according to the level of inflammatory reactions (inflammatory infiltrate) and reparative processes (fibrosis, angioblastic and fibroblastic proliferation).

In the blank control group (contra lateral sides with surgical incisions), was possible to observe a granulation tissue rich in fibroblasts and blood capillaries, as well as large macrophages. 
Acta Veterinaria (Beograd), Vol. 59. No. 2-3, 243-253, 2009.

Marković Danica et al.: Histological and immunohistochemical

Table 2. Grading system for microscopic examination of soft tissue reaction

\begin{tabular}{|c|c|c|c|c|c|c|c|c|c|c|c|c|}
\hline \multirow{2}{*}{ Reaction } & & \multicolumn{11}{|c|}{ Numerical grading } \\
\hline & & \multirow{2}{*}{$\mathrm{HI}$} & \multirow{2}{*}{$\mathrm{DC}$} & \multicolumn{2}{|c|}{$\mathrm{HI}, \mathrm{TCP} 22$} & \multicolumn{3}{|c|}{ HITCP45 } & \multicolumn{2}{|c|}{ HI, HAP22 } & \multicolumn{2}{|c|}{ HI, HAP45 } \\
\hline \multicolumn{11}{|c|}{ 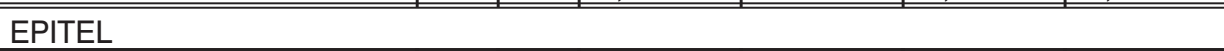 } & & \\
\hline Normal, intact & 0 & 1 & 1 & 1 & 1 & 1 & 1 & & 1 & 1 & 1 & 1 \\
\hline Cell degeneration & 1 & & & & & & & & & & & \\
\hline Metaplasia & 2 & & & & & & & & & & & \\
\hline Focal erosion & 3 & & & & & & & & & & & \\
\hline Generalized erosion & 4 & & & & & & & & & & & \\
\hline \multicolumn{13}{|c|}{ LEUCOCYTE INFILTRATION (per high power fild) } \\
\hline Absent & 0 & & & & & \multirow{5}{*}{\multicolumn{2}{|c|}{3}} & \multirow{5}{*}{\multicolumn{3}{|c|}{2}} & \multirow{5}{*}{1} & \\
\hline Minimal (less than 25) & 1 & 1 & & 1 & & & & & & & & \\
\hline Mild (26-50) & 2 & & 2 & & 2 & & & & & & & \\
\hline Moderate ( $51-100)$ & 3 & & & & & & & & & & & \\
\hline Marked (up to 100) & 4 & & & & & & & & & & & 4 \\
\hline \multicolumn{13}{|c|}{ VASCULAR CONGESTION } \\
\hline Absent & 0 & & & & & \multirow{5}{*}{\multicolumn{2}{|c|}{3}} & \multirow{5}{*}{\multicolumn{3}{|c|}{2}} & \multirow{5}{*}{1} & \\
\hline Minimal & 1 & 1 & & 1 & & & & & & & & \\
\hline Mild & 2 & & 2 & & 2 & & & & & & & \\
\hline Moderate & 3 & & & & & & & & & & & \\
\hline $\begin{array}{l}\text { Marked, with } \\
\text { disruption of vessels }\end{array}$ & 4 & & & & & & & & & & & 4 \\
\hline \multicolumn{13}{|l|}{ OEDEMA } \\
\hline Absent & 0 & \multirow{5}{*}{1} & \multirow{5}{*}{2} & \multirow{5}{*}{\multicolumn{2}{|c|}{1}} & \multirow{5}{*}{\multicolumn{2}{|c|}{2}} & \multirow{5}{*}{\multicolumn{2}{|c|}{1}} & & & \\
\hline Minimal & 1 & & & & & & & & & & & \\
\hline Mild & 2 & & & & & & & & & & 2 & \\
\hline Moderate & 3 & & & & & & & & & & & \\
\hline Marked & 4 & & & & & & & & & 4 & & 4 \\
\hline \multicolumn{13}{|l|}{ CAPSULE } \\
\hline Absent & 0 & 0 & \multirow{5}{*}{2} & \multirow{5}{*}{\multicolumn{2}{|c|}{0}} & \multirow{5}{*}{\multicolumn{2}{|c|}{0}} & & 0 & & 0 & \\
\hline Minimal & 1 & & & & & & & & & & & \\
\hline Mild / thin & 2 & & & & & & & & & & & \\
\hline Moderate & 3 & & & & & & & & & 3 & & \\
\hline Marked / thick & 4 & & & & & & & & & & & 4 \\
\hline
\end{tabular}

A fibrous capsule and an inflammatory reaction were present surrounding the implants. The inflammatory infiltrate consisted mostly of lymphocytes, macrophages and polimorphonuclears. The inflammatory reactions varied from mild to severe (Figure 2). The thickness varied from thinnest for DC and TCP22 
evaluated as mild, moderate for TCP45 and HAP22, and marked, very thick for HAP45.

In all test samples at the contra lateral sides of the blank control a line of surgical incision from the epidermis to cutaneous muscle was noted, and was characterized with the presence of fibroblasts, fibrocytes, angioblasts and collagen fibers.

The subcutaneous connective tissue was mildly to moderately oedematous, containing macrophages, lymphocytes, eosinophils, and siderophages. These changes were graded from 1 (mild) to 4 (marked) according to $\mathrm{BCM}$ response differences.

Moderate fibroblastic and angioblastic proliferation and mild fibrosis were detected in the adjusting soft tissue. Small foci of macrophages containing phagocyted material were seen (Figure 3), the most remarkable in HAP45 specimen. In same test samples a marked presence of eosinophiles was observed.

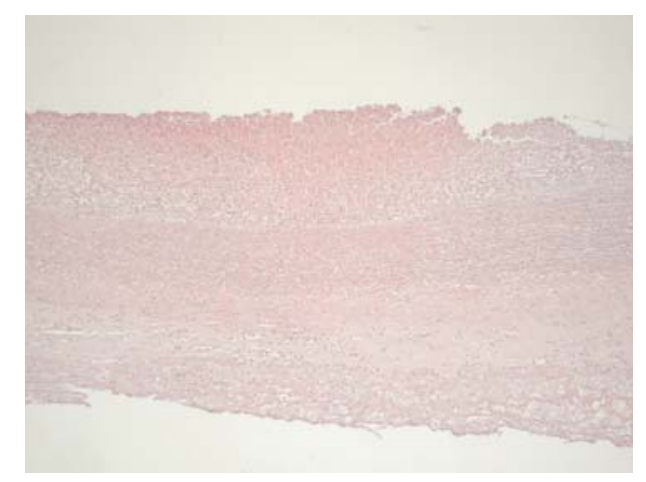

Figure 2. (H\&E, 10x). HAP45. The thick capsule with numerous infiltrate cell populations

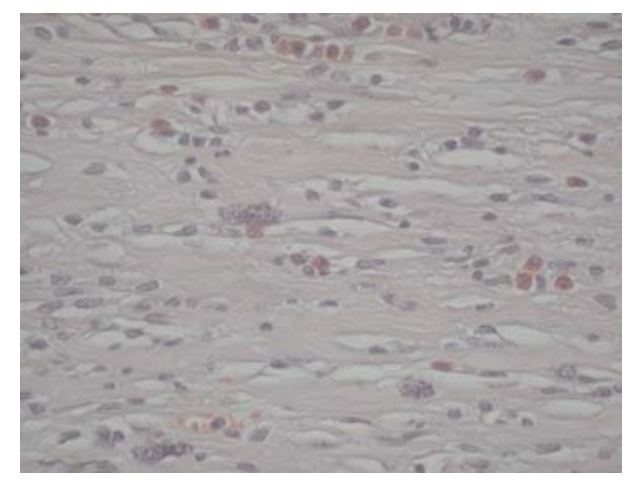

Figure 3. (H\&E, 100x). HAP45. Eosinophiles, macrophages, lymphocytes among collagenous fibers infiltrating the loose connective tissue of the capsule

In total immunohistological (IHC) evaluations of tissue response in all tested groups, comparing the contra lateral sides with surgical incision (SI) and graft implant response of tissue, mild CD3+ response in the epidermis, dermis, subcutis and cutaneous muscle was noted.

The test sides including BCM had various responses evaluated from mild to severe, mild in DC, moderate at HAP22, TCP22, TCP45, and marked at HAP45.

The results are illustrated in Table 3., Table 4 and Figure 4. 
Acta Veterinaria (Beograd), Vol. 59. No. 2-3, 243-253, 2009

Marković Danica et al.: Histological and immunohistochemical

evaluations of rat soft tissue response to bioceramical implants

A
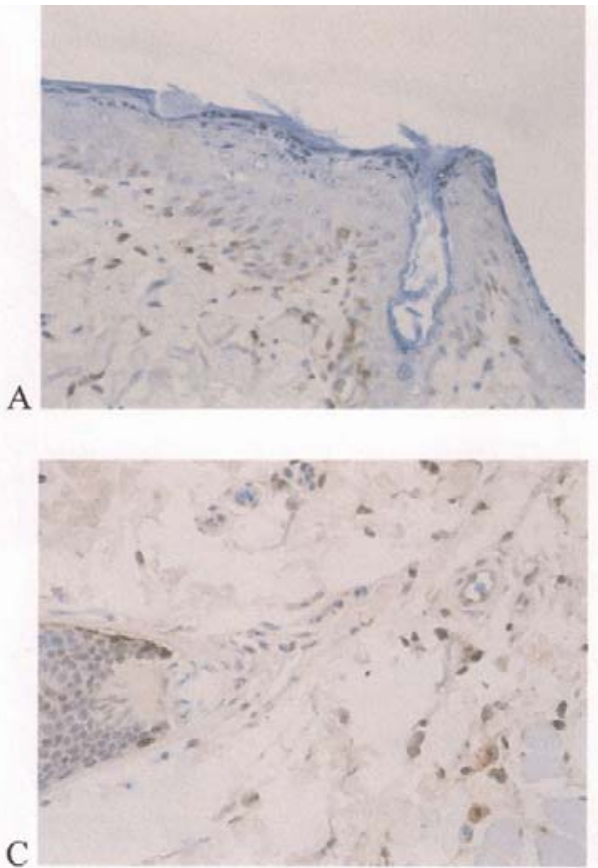

B

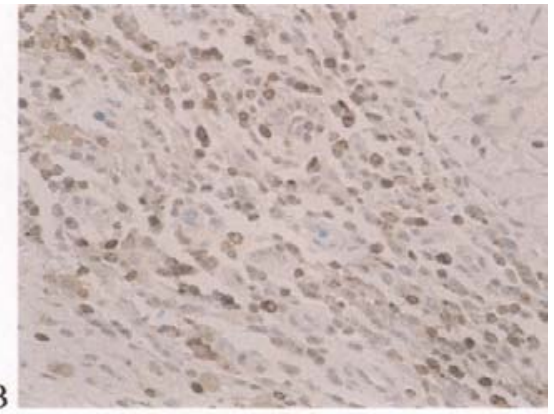

D

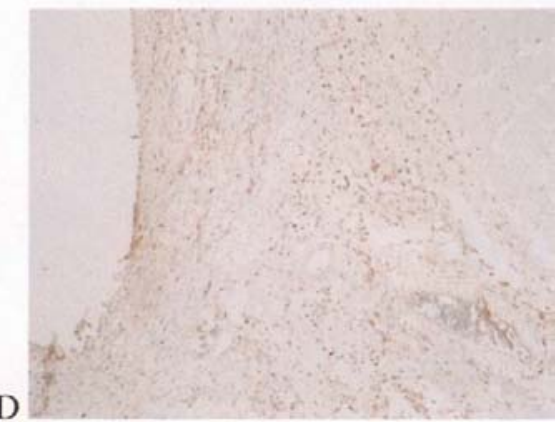

Figure 4. (IHC), CD3 positive staining in the soft tissue of tested animals. (A) SI on tested animals presented with concentrated CD3 + cells at the area of healing subepidermal soft tissue, 100x. (B) HAP45, the marked presence of CD3+ cells in deep subcutis surrounding the graft place, 100x. (C) DC, at adjacent graft implant soft tissue mild assigned CD3 + cells adjacent to hair follicle, 100x (D) TCP45, moderate presence of CD3+ cells in subcutis around the graft place, $10 x$

Table 3.Semi-quantitative evaluation of Proportional index (PI) CD3+ cells in soft tissue of surgical incisions (SI) and bioceramic materials (BCM) implant sites, IHC

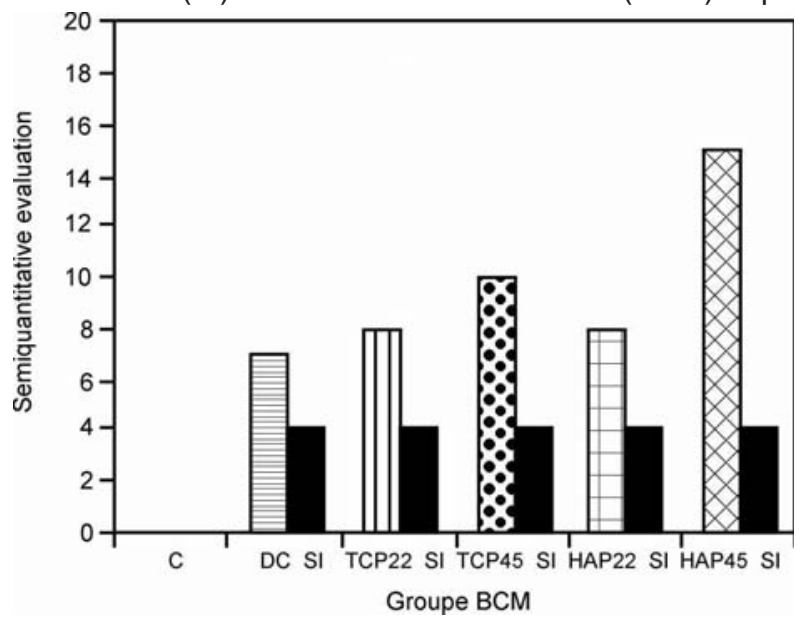


Table 4. Semi-quantitative evaluations of $\mathrm{CD} 3+$ cells $\mathrm{IHC}$ labelled in particular layers of soft tissue in tested animals grading lymphocite (CD3) presence in SI and BCM samples
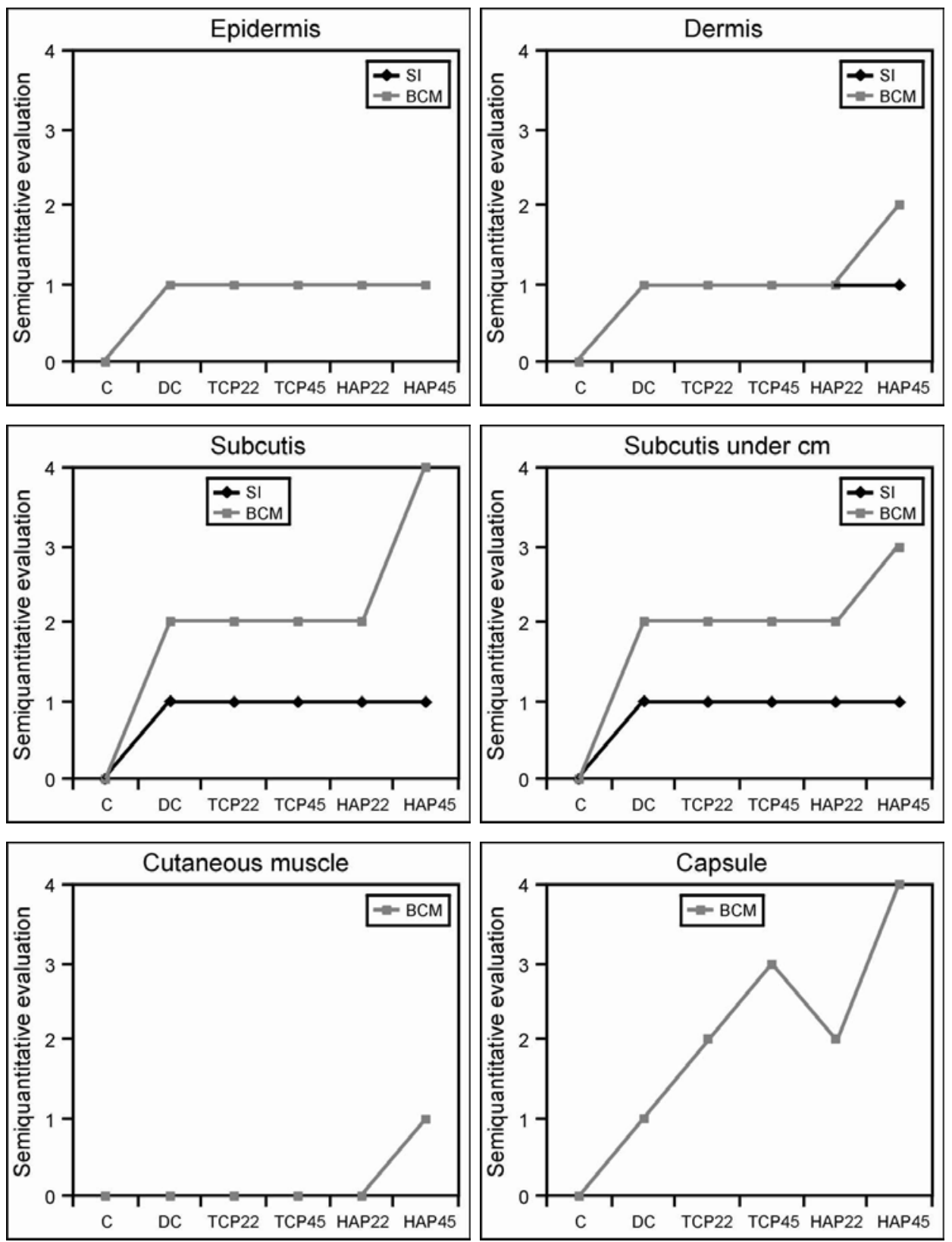


\section{DISCUSSION}

Disruption of structural and functional integrity of the skin, caused by different factors, induces an overlapping pattern of events including haemostasis, inflammation and epithelization, as well as formation of granulation tissue and tissue remodelling (Todorovic et al., 2008). Few hours after injury the wound site is invaded with inflammatory cells: neutrophils, first, than monocytes, macrophages, fibroblasts and lymphocytes (Diegelman et al., 2004). After 3 days the collagen fibrils can be seen in the linear incision of the skin (Werner et al., 2003). Many of the growth factors and cytokines are released at that time. As the proliferative phase progresses, the predominant cells in the wound site are reparatory cells producing the new matrix needed for structure and function repair of the injured tissue (Whitney, 2005).

In the presence of graft implants of BCM materials due to foreign bodytissue reaction, and moreover, specific biocompatible or noncompatible response of host tissue develops (Bernath and Szabo, 2003). A variety of artificial materials has been used to fill in bone defects. Ideally, bone grafts should be biocompatible, causing minimal fibrotic reactions. They should undergo remodelling and support new bone formation. Generally, bioactive ceramics have the ability to bond directly to bone tissue, and have both osteointegrative and osteoinductive properties, at the same tame having improved mechanical properties over other bone substitutes (Danilovic et al., 2007).

In the search for ideal biocompatible materials many different methods have been described for assessing tissue toxicity (Spangberg, 1988.) In vivo experimental models must be used to obtain answers to local tissue response to bioceramical implants (Pissiotis and Spangberg, 2000; Ozbes et al., 2003; Saidon et al., 2003). The majority of studies have been performed on soft tissue (Stojanovic et al., 2008). Spangberg (1990) commented that such implantation was easy to do and required minor surgical skills. The observation period after inserting implants must be established in such a way that both short-term reactions, as well as long-term healing can be observed. It is important to obtain information about the initial effect of bio ceramic materials on tissue. Surgical implantation introduces such tissue trauma and subsequent surgical inflammation that it becomes practically impossible to distinguish the tissue response from that created by the material being investigated (Spangberg, 1990).

The implanted materials led to moderate or severe inflammatory responses initially, but the response decreased in time with an increasingly thickening fibrous connective tissue capsule forming around the grafts. This response is moderate at the beginning and it is decreasing in magnitude with time. This form of reaction is in agreement with the Dental Association technical requisites (ANSI/ADA, 1982) in determining a material as biologically acceptable.

\section{CONCLUSION}

The examined tissue samples showed mild inflammatory tissue reactions, primarily due to surgical trauma. 
The most reactive tissue was under the influence of HAP45 implants, where in the tissue surrounding the graft lymphocytes, macrophages, siderophages, plasmocytes, mastocytes and eosinophiles were observed. In same cases the widest capsule was presented with swelling surrounding tissue.

The test material comparing with surgical incision wounds induced a foreign body - type granuloma with subsequent fibrosis around the graft implants, presence of capsule at interface with BCM in rat subcutaneous tissue and did not elicit any remarkable immune response, thus upon evaluation are considered biocompatible.

\author{
Address for correspondence: \\ Markovic Danica \\ Department of Histology and Embriology \\ Faculty of Veterinary Medicine \\ University of Belgrade \\ Bulevar oslobođenja 18 \\ 11000 Belgrade, Serbia \\ E-mail: danicams@eunet.yu
}

\title{
REFERENCES
}

1. American National Standards Institute / American dental Association (ANSI/ADA), 1982, Document No 41 for recommended standard practices for biological evaluation of dental materials. Washington DC: Government Printing Office.

2. Bernath M, Szabo M, 2003, Tissue reaction initiated by different sealers. Into Endod J, 36, 256-61.

3. Butler D, Goldstein S, Guilak F, 2000, Functional tissue engineering: the role of biomechanics, J Biomech Eng, 122, 6, 570-5.

4. Danilovic V, Krsljak E, Lackovic V, 2007, Histological evaluation of odontoblast-like cells response after capping application of calcium hydroxide and hydroxilapatite in dogs pulp, Acta Vet Beograd, 57, 5-6, 573-84.

5. Diegelmann R, Evans $M, 2004$, Wound healing: an overview of acute, fibrotic and delayed healing, Front Biosci, 9, 283-9.

6. Janackovic Dj, Jankovic I Petrovic R, Kostic-Gvozdenovic LJ, Milonjic S, Uskokovic D, 2003, Surface properties of HAP particles obtained by Hydrothermal decomposition urea and calcium-EDTA chelates, Key Engineering Materials, 240-2, 437-40.

7. Hardingham T, Fusing A, 1992, Proteoglycans: many forms and many functions, Faseb J, 6, 3, 86170.

8. Krsljak E, Danilovic V,Teodorovic N, 2005, Histological evaluation of bone response to bioactive ceramics as graft material in rats, Acta Vet Beograd, 55, 5-6, 461-70.

9. Mow V, Ateshian A, Lai W, Gu W, 1998, Effects of fixed charges on the stress-relaxation behaviour of hydrated soft tissue in a confined compression problem, Int J Solids Stru, 35, 4945-62.

10. Ozbas $H$, Yaltiric $M$, Bilgic $B$, Issever $H, 2003$, Reactions of connective tissue to compomers, composite and amalgam root / end filling materials, Int Endod J, 36, 281-7.

11. Pissiotis E, Spanglerg L, 2000, Reaction of bony tissue to implanted silver glass ionomer and a reinforced Zinc oxide-eugenol cement, Oral Surg Oral Med Oral Pathol Oral Radiol Endod, 89, 623-9.

12. Saidan J, He J, Zhu Q, Safavi K, Spangberg L, 2003, Cell and tissue reaction to mineral trioxide aggregate and portland cement, Oral Surg Oral Med Oral Pathol Oral Radiol Endod, 95, 483-9.

13. Spangberg L, 1988, Correlation of in vivo and in vitro screening test. Endodontia, 4296-9.

14. Spangberg L. editors, 1990, Experimental endodontics $1^{\text {st }}$ ed., Florida:CRC Press Inc, 173-210. 
15. Stojanovic D, Janackovic Dj, Markovic D, Tasic G, Kojic Z, 2008, A tissue-implant reaction associated with subcutan implantation of alpha-tricalcium phosphate, dental ceramic, and hydroxyapatite bioceramics in rats, Acta Vet Beograd, 58, 4, 381-93.

16. Sun D, Leong K, 2003, Functional Engineering of Load-supporting Soft Tissues, Bioengineering, 9 , 97-131.

17. Tamai M, Isama $K$, Nakaoka $R$, Tsuchiya $T$, 2007, Synthesis of a novel $\beta$-tricalcium phosphate/hydroxyapatite biphasic calcium phosphate containing niobium ions and evaluation of its osteogenic properties, J Artif Organs, 10, 22-8.

18. Todorovic V, Pesko P, Micev M, Bjelovic M, Budec M, Micic M et al, 2008, Insulin - like Growth factor- I in Wound Healing of Rat Skin, Regulatory Peptides, 3847, in press.

19. Upman PJ, Muench T, 2004, Comprehensive Scoring System for Biomaterial Implants, Amer. College of Toxicology presentation, Nov 7-10. Int J Toxicol, 23, P384

20. Whitney J, 2005, Overview: Acute and chronic wounds, Nurse Clin N Am, 40, 191-20.

21. Werner S, Grose R, 2003, Regulation of wound healing by growth factors and cytokines, Physiol Rev, 83, 835-70.

\title{
HISTOLOŠKA I IMUNOHISTOHEMIJSKA PROCENA REAKCIJE MEKOG TKIVA PACOVA NA BIOKERAMIČKE IMPLANTE
}

\author{
MARKOVIĆ DANICA, KOJIĆ ZVEZDANA, MARINKOVIĆ D, DANILOVIĆ VESNA, \\ RADOVANOVIĆ ANITA i JANAĆKOVIĆ Đ
}

\section{SADRŽAJ}

Svrha ove studije je bila procena tkivnog odgovora indukovanog biokeramičkim materijalima (BCM) inplantiranim u subkutano tkivo pacova. Trideset dva pacova je bilo podeljeno u sledećih 6 grupa: kontrolna grupa-neoperisana; inplantirane sa: dentalnom keramikom (DC); alfa trikalcijum fosfatima sintetisanim na $22 \mathrm{MPa}(\alpha \mathrm{TCP} 22)$ i na $45 \mathrm{MPa}(\alpha \mathrm{TCP} 45)$; hidroksiapatitom sintetisanim na 22 MPa (HAP22) i na 45 MPa (HAP45). Kontralateralne strane svih životinja bile su slepa kontrola i urađene su kao džepovi hirurške incizije u subkutanom tkivu. Eksperimentalne grupe su imale subkutano inplantirane biokeramičke materijale. Uzorci su sakupljeni posle 14 dana i sprovedeni u histološkoj proceduri, a inflamatorna reakcija je praćena mikroskopski. Inflamatorni infiltrat se sastojao od limfocita, polimorfonuklearnih leukocita, makrofaga i mastocita. Istovremeno su uočeni znaci rastuće fibroze oko mesta graftova.

Inplantirana mesta u poređenju sa hirurškim ranama indukuju granulom karakterističnog tipa na strano telo sa posledičnom fibrozom oko graftova, kapsulom na dodirnoj površini sa BCM u subkutisu pacova, ne izazivajući uočljivu imunološku reakciju, tako da odgovor tkiva ukazuje na biokompatibilnost. Procenjivanjem odgovora sa različitim BCM, zabeležena je najintenzivnija (snažna) tkivna reakcija kod HAP45 inplanta, a blaga do umerena kod DC, HAP22 i alfa trikalcijumfosfata. 